\title{
Insulin Modulates Cocaine-Sensitive Monoamine Transporter Function and Impulsive Behavior
}

\author{
Anton N. M. Schoffelmeer, Benjamin Drukarch, Taco J. De Vries, François Hogenboom, Dustin Schetters, \\ and Tommy Pattij \\ Department of Anatomy and Neurosciences, Neuroscience Campus Amsterdam, VU University Medical Center, 1081 BT Amsterdam, The Netherlands
}

\begin{abstract}
Because insulin acutely enhances the function of dopamine transporters, the tyrosine kinase receptors activated by this hormone may modulate transporter-dependent neurochemical and behavioral effects of psychoactive drugs. In this respect, we examined the effects of insulin on exocytotic monoamine release and the efficacy of the monoamine transporter blocker cocaine in rat nucleus accumbens. Whereas insulin reduced electrically evoked exocytotic $\left[{ }^{3} \mathrm{H}\right]$ dopamine release in nucleus accumbens slices, the hormone potentiated the release-enhancing effect of cocaine thereon. The phosphatidylinositol 3-kinase inhibitor LY294002 abolished these effects, indicating the involvement of insulin receptors. Similar insulin effects were observed on the release of $\left[{ }^{3} \mathrm{H}\right]$ norepinephrine in nucleus accumbens slices, but not on that of $\left[{ }^{3} \mathrm{H}\right]$ serotonin, and were also apparent in medial prefrontal cortex slices. As might then be expected, insulin also potentiated the dopamine and norepinephrine release-enhancing effects of the selective monoamine uptake inhibitors GBR12909 and desmethylimipramine, respectively. In subsequent behavioral experiments, we investigated the role of insulin in motor impulsivity that depends on monoamine neurotransmission in the nucleus accumbens. Intracranial administration of insulin in the nucleus accumbens alone reduced premature responses in the five-choice serial reaction time task and enhanced the stimulatory effect of peripheral cocaine administration on impulsivity, resembling the observed neurochemical effects of the hormone. In contrast, cocaine-induced locomotor activity remained unchanged by intra-accumbal insulin application. These data reveal that insulin presynaptically regulates cocainesensitive monoamine transporter function in the nucleus accumbens and, as a consequence, impulsivity. Therefore, insulin signaling proteins may represent targets for the treatment of inhibitory control deficits such as addictive behaviors.
\end{abstract}

\section{Introduction}

The pancreatic hormone insulin rapidly crosses the blood-brain barrier and activates insulin receptors that are widely expressed throughout the brain (Woods et al., 2000). These tyrosine kinase receptors are enriched in neurons and found in cell bodies and nerve terminal membranes of neurons in hypothalamic and higher limbic regions (Marks et al., 1988; Schulingkamp et al., 2000). Accordingly, insulin not only acts at hypothalamic sites as regulator of energy homeostasis in the periphery, but may also modulate cognitive performance and motivation (Kern et al., 2001; Zhao and Alkon, 2001; Figlewicz and Benoit, 2009). Notably, neuronal activity in the brain evoked by a peripheral insulin injection was attenuated in nondiabetic humans with peripheral insulin resistance, being most marked in the nucleus accumbens (NAc) and medial prefrontal cortex (mPFC). Hence, central insulin resistance may exist in peripheral insulin resistance in brain regions that play an important role in cognition and motivation (Anthony et al., 2006).

Regarding the role of insulin in the behavioral effects of natural reinforcers and addictive drugs, the hormone appeared to

Received July 21, 2010; revised 0ct. 25, 2010; accepted Nov. 18, 2010.

Correspondence should be addressed to Dr. Anton N. M. Schoffelmeer, Department of Anatomy and Neurosciences, VU University Medical Center, Van der Boechorststraat 7, 1081 BT Amsterdam, The Netherlands. E-mail: anm.schoffelmeer@vumc.nl.

DOI:10.1523/JNEUROSCI.3779-10.2011

Copyright $\odot 2011$ the authors $\quad 0270-6474 / 11 / 311284-08 \$ 15.00 / 0$ acutely enhance the clearance of synaptically released dopamine (DA) by increasing the cell surface expression and/or function of the DA transporter (DAT) in DA nerve terminals (Patterson et al., 1998; Owens et al., 2005; Williams et al., 2007; Lute et al., 2008; Figlewicz and Benoit, 2009). Since DAT is a major target for amphetamine and cocaine (Giros et al., 1996; Rothman and Baumann, 2003), insulin receptors might therefore play a role in the cognitive and/or motivational effects of psychostimulants. Considering the regulatory role of insulin in central monoamine release, studies have primarily focused on the effects of amphetamine on nonexocytotic DA release in the striatum of insulindepleted rats and on DA release from cultured neurons. Such studies revealed that activation of insulin receptors, via stimulation of the insulin receptor substrate-2 (IRS-2)/phosphatidylinositol 3-kinase (PI3K) pathway, sustains DAT function in DA nerve terminals (Williams et al., 2007: Lute et al., 2008), which is required for psychostimulants to enhance DA neurotransmission (Khoshbouei et al., 2004).

To examine such a role of insulin in monoamine transporter function in nondiabetic rats, we investigated the effects of NAc insulin on cocaine-sensitive exocytotic monoamine release and on inhibitory response control (motor impulsivity). To that end, the effects of insulin on the electrically evoked release of (radiolabeled) DA, norepinephrine (NE) and serotonin [5-hydroxytryptamine (5HT)], and the transporter-dependent release-enhancing effects of cocaine were studied in superfused NAc slices. Considering the region-specificity of these effects, such experiments were also 
performed with slices of the caudate putamen (CP), the mPFC, and the orbitofrontal cortex (OFC). Moreover, we examined the effects of intracranial insulin infusions in the NAc on motor impulsivity induced by intraperitoneal administration of cocaine by means of the five-choice serial reaction time task (5-CSRTT), designed to tax monoamine-dependent inhibitory response processes (Cole and Robbins, 1989; Pattij and Vanderschuren, 2008). Finally, to investigate whether insulin may affect behaviors that engage monoamine neurotransmission in general, the locomotor effects of NAc insulin were also studied.

\section{Materials and Methods}

Subjects. Male Wistar rats ( 250 g; Harlan) were housed in pairs in Macrolon cages under a reversed $12 \mathrm{~h}$ light/dark cycle (lights on at 7:00 P.M.) at controlled room temperature $\left(21 \pm 2^{\circ} \mathrm{C}\right)$ and relative humidity of $60 \pm 15 \%$. For the 5 -CSRTT experiments, animals were maintained at $\sim 90 \%$ of their free-feeding weight, starting 1 week before the beginning of the experiments by restricting the amount of standard rodent food pellets (Harlan Teklad Global Diet). Water was available ad libitum throughout the entire experiment. All experiments were conducted with the approval of the animal ethical committee of the VU University.

Materials. $\left[{ }^{3} \mathrm{H}\right]$ norepinephrine $(35 \mathrm{Ci} / \mathrm{mmol}),\left[{ }^{3} \mathrm{H}\right] 5$-hydroxytryptamine $(15.9 \mathrm{Ci} / \mathrm{mmol})$, and $\left[{ }^{3} \mathrm{H}\right]$ dopamine $(41 \mathrm{Ci} / \mathrm{mmol})$ were purchased from the Radiochemical Center (GE Healthcare). Insulin, desmethylimipramine, and fluvoxamine were obtained from Sigma, GBR12909 from Research Biochemicals, LY294002 from Calbiochem, and leptin from Bachem. Cocaine hydrochloride was obtained from OPG.

Superfusion of brain slices. Rats were decapitated, their brains rapidly removed, and the NAc, mPFC, CP, or OFC dissected from 1-mm-thick coronal slices using the atlas of Paxinos and Watson (1986). Slices $(0.3 \times$ $0.3 \times 1 \mathrm{~mm}$ ) were prepared using a McIlwain tissue chopper. For each experiment, brain slices from six animals were pooled, then incubated with radiolabeled DA, NE, or 5-HT as described previously (Schoffelmeer et al., 1988). In short, slices were washed twice with $5 \mathrm{ml}$ of Krebs-Ringer's bicarbonate medium containing the following (in $\mathrm{mm}$ ): $121 \mathrm{NaCl}, 1.87 \mathrm{KCl}, 1.17 \mathrm{KHPO}_{4}, 1.17 \mathrm{MgSO}_{4}, 25 \mathrm{NaHCO}_{3}, 1.2 \mathrm{CaCl}_{2}$, and $10 \mathrm{D}-(+)$ glucose, $\mathrm{pH}$ 7.4. Subsequently, the slices were incubated for $15 \mathrm{~min}$ in this medium, containing either $5 \mu \mathrm{Ci}\left[{ }^{3} \mathrm{H}\right] \mathrm{DA},\left[{ }^{3} \mathrm{H}\right] \mathrm{NE}$, or $\left[{ }^{3} \mathrm{H}\right] 5-\mathrm{HT}$ under an atmosphere of $95 \% \mathrm{O}_{2}-5 \% \mathrm{CO}_{2}$ at $37^{\circ} \mathrm{C}$. Incubation of the slices with $\left[{ }^{3} \mathrm{H}\right] \mathrm{DA}$ was performed in the presence of $3 \mu \mathrm{M}$ of the selective NE transporter (NET) inhibitor desmethylimipramine to prevent accumulation of $\left[{ }^{3} \mathrm{H}\right] \mathrm{DA}$ in noradrenergic nerve terminals, and incubation with $\left[{ }^{3} \mathrm{H}\right] \mathrm{NE}$ and $\left[{ }^{3} \mathrm{H}\right] 5-\mathrm{HT}$ was done in the presence of 10 $\mu \mathrm{M}$ of the selective DAT inhibitor GBR12909 to prevent their accumulation in dopaminergic nerve terminals. After labeling, the slices were washed and transferred to each of 24 chambers of a superfusion apparatus ( $\sim 3 \mathrm{mg}$ tissue per chamber, $0.2 \mathrm{ml}$ volume) and superfused $(0.25$ $\mathrm{ml} / \mathrm{min}$ ) with medium gassed with $95 \% \mathrm{O}_{2}-5 \% \mathrm{CO}_{2}$ at $37^{\circ} \mathrm{C}$. The superfusate was collected as $10 \mathrm{~min}$ samples. After $40 \mathrm{~min}$ of superfusion $(t=$ $40 \mathrm{~min}$ ), calcium-dependent and tetrodotoxin-sensitive (exocytotic) neurotransmitter release was induced during superfusion by exposing the slices to electrical biphasic 2 ms block pulses $\left(\left[{ }^{3} \mathrm{H}\right] \mathrm{NE}\right.$ release: $1 \mathrm{~Hz}$, $10 \mathrm{~mA}$ current; [ $\left.{ }^{3} \mathrm{H}\right] \mathrm{DA}$ and $\left[{ }^{3} \mathrm{H}\right] 5$-HT release: $1 \mathrm{~Hz}, 30 \mathrm{~mA}$ current) for 10 min (electrical-field stimulation). Drugs (insulin, cocaine, LY294002, desmethylimipramine, fluvoxamine, GBR12909, and leptin) were added to the medium $20 \mathrm{~min}$ before electrical stimulation of the slices and remained present until the end of the experiment. In each experiment, six observations and experiments were repeated three or four times.

Calculation of release data. To determine exocytotic neurotransmitter release in the slices, the radioactivity remaining at the end of the superfusion experiment was extracted from the tissue with $0.1 \mathrm{~N} \mathrm{HCl}$. The radioactivity in superfusion fractions and tissue extracts was determined by liquid scintillation counting. The efflux of radioactivity during each collection period was expressed as a percentage of the amount of radioactivity in the slices at the beginning of the respective collection period. The electrically evoked neurotransmitter release was calculated by subtracting the spontaneous efflux of radioactivity from the total overflow of radioactivity during stimulation and the following $10 \mathrm{~min}$. Because neurotransmitter release returned to basal levels during the next $10 \mathrm{~min}$ period, a linear decline from the $10 \mathrm{~min}$ interval before to the $20-30 \mathrm{~min}$ after the onset of stimulation was assumed for calculation of spontaneous efflux of radioactivity. Independent of the brain region investigated, this spontaneous efflux of radioactivity amounted to $\sim 3 \%$ of total tissue radioactivity in slices labeled with $\left[{ }^{3} \mathrm{H}\right] \mathrm{DA}$ or $\left[{ }^{3} \mathrm{H}\right] \mathrm{NE}$ and to $\sim 9 \%$ of total tissue radioactivity in slices labeled with $\left[{ }^{3} \mathrm{H}\right] 5-\mathrm{HT}$. At the concentrations used, none of the drugs examined altered spontaneous tritium efflux from the slices. The electrically evoked release was expressed as percentage of the content of radioactivity of the slices at the start of the stimulation period.

The effects of drugs on evoked neurotransmitter release in excess of spontaneous efflux were analyzed using one-way ANOVA's, followed by Student's Newman-Keuls tests where appropriate. The level of probability for statistically significant effects was set at 0.05 (NS, not significant).

Behavioral training in the five-choice serial reaction time task. Detailed description of the behavioral apparatus and training in the 5-CSRTT has been provided previously (van Gaalen et al., 2006). In short, rats were trained to detect and respond to a $1 \mathrm{~s}$ visual stimulus in one of five apertures, during presentation of the stimulus, or during a $2 \mathrm{~s}$ limited hold period to obtain a food reward ( $45 \mathrm{mg}$, Formula P; Research Diets). Each session terminated after 100 trials or $30 \mathrm{~min}$, whichever occurred first. Initially, the duration of this stimulus was $32 \mathrm{~s}$ and was gradually decreased to $1 \mathrm{~s}$ over sessions until animals reached stable baseline performance (accuracy, $>80 \%$ correct choice and $<20 \%$ errors of omission). Incorrect, premature responses (responses during the $5 \mathrm{~s}$ intertrial interval) and errors of omission did not lead to the delivery of a food reward and resulted in a $5 \mathrm{~s}$ time-out period during which the house light was extinguished. Responses during the time-out period resulted in a new time-out period. Perseverative responses, i.e., repeated responding during the presentation of the stimulus were measured but did not have any programmed consequences. The following behavioral measures were recorded: (1) percentage premature responses [(number premature responses $) /($ correct + incorrect responses + omissions $) \times 100]$, (2) accurate choice $[$ (number correct responses)/(correct + incorrect responses) $\times 100]$, (3) latency of correct responses, (4) percentage omissions [(number omissions)/(correct + incorrect responses + omissions $) \times 100]$, (5) feeder latency, i.e., time to collect food reward after correct choice, and (6) perseverative responses after correct choice.

Behavioral data were analyzed using two-factor repeated-measures ANOVAs with insulin (vehicle or insulin) and cocaine (saline or cocaine) treatment as within-subject factors. Significant insulin $\times$ cocaine interaction effects indicate differential effects of insulin on cocaine's effects on performance. In case of significant interaction effects, further analyses were conducted using paired-samples $t$ tests.

Surgery and infusion procedure. Three days before surgery, the food restriction schedule in 5-CSRTT experiments was terminated and rats had ad libitum access to food. For surgery, rats were anesthetized using a combination of xylazine (Rompun, $7 \mathrm{mg} / \mathrm{kg}$, i.p.; Bayer) and ketamine (100 mg/kg, i.m.; Alfasan), then placed in a stereotaxic instrument (David Kopf Instruments) for placement of an indwelling bilateral guide cannula (model C235G; Plastics One). The coordinates used for placement of the cannulae in the NAc were as follows: $1.7 \mathrm{~mm}$ rostral to bregma, $6.4 \mathrm{~mm}$ ventral to the skull, and $1.0 \mathrm{~mm}$ lateral to midline calculated from Paxinos and Watson (1998). Following surgery, the animals were housed individually and had ad libitum access to food 1 week before retraining in the 5-CSRTT.

Intracranial infusions in the 5-CSRTT experiments were performed when stable baseline performance was reestablished, and during this period animals were habituated twice to intraperitoneal saline injections. Initially, during two sham infusion sessions, animals were habituated to insertion of a bilateral injector extending $1 \mathrm{~mm}$ beyond the guide cannula (model C235I; Plastics One). During the infusion experiments, insulin (2 $\mu \mathrm{M}$ ) or vehicle was infused over a period of $1 \mathrm{~min}$ at a rate of $0.5 \mu \mathrm{l} / \mathrm{min}$ using $10 \mu \mathrm{l}$ Hamilton syringes driven by a syringe infusion pump (Harvard Apparatus). Following infusion, the injector remained in place for an additional minute to allow diffusion of insulin; the rats were tested 10 min later. For the combination study of insulin pretreatment and intra- 

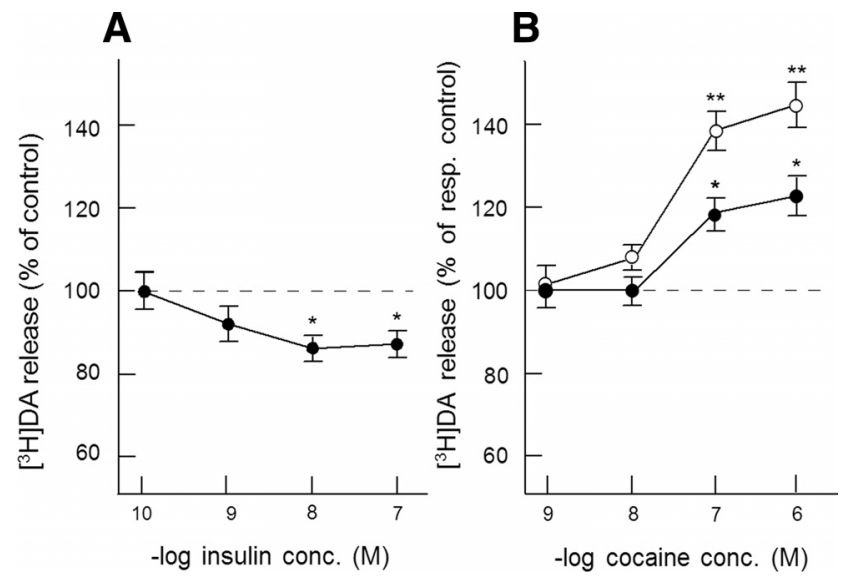

Figure 1. $\quad \boldsymbol{A}, \boldsymbol{B}$, The effect of insulin on the electrically evoked $\left[{ }^{3} \mathrm{H}\right] \mathrm{DA}$ release $(\boldsymbol{A})$ and on the release-enhancing effect of cocaine $(\boldsymbol{B})$ in NAc slices. Slices, incubated with $\left[{ }^{3} \mathrm{H}\right] \mathrm{DA}$ (in the presence of $3 \mu \mathrm{m}$ desmethylimipramine), were superfused and stimulated electrically at $t=40 \mathrm{~min}$ for $10 \mathrm{~min}$. Insulin and cocaine were added to the superfusion medium 20 min before depolarization and were present until the end of the experiment. Data are expressed as percentage of electrically evoked $\left[{ }^{3} \mathrm{H}\right] \mathrm{DA}$ release observed in the absence of insulin $(\boldsymbol{A})$ and as percentage of electrically evoked [ $\left.{ }^{3} \mathrm{H}\right] \mathrm{DA}$ release in the absence (closed circles) or presence (open circles) of $10 \mathrm{~nm}$ insulin $(\boldsymbol{B})$. Data represent means \pm SEM of $24-30$ observations. ${ }^{*} p<0.05$, significantly different from control release; ${ }^{* *} p<0.05$, significantly different from effect of cocaine in the absence of insulin. resp. control, Respective control; conc., concentration.

peritoneal cocaine, immediately following the infusion procedure rats were injected with vehicle or cocaine $(5 \mathrm{mg} / \mathrm{kg}$ ) and tested $10 \mathrm{~min}$ later.

Measurement of locomotor activity. For the locomotor activity experiments, animals were equipped with bilateral cannulae aimed at the NAc, as described above. Horizontal motor activity was measured in Perspex cages $(40 \times 40 \times 35 \mathrm{~cm})$ using a video tracking system (Ethovision Pro v. 2.3.21; Noldus Information Technology), which determined the position of the animal five times per second. All experiments were conducted between 9:30 A.M. and 4:30 P.M. in the dark phase of the day/night cycle. Locomotor activity was assessed. On $\mathrm{d} 1$, animals were allowed to habituate to the test cage for $2 \mathrm{~h}$, during which activity was monitored. On d 2, the rats were again habituated to the test cage for $1 \mathrm{~h}$, after which insulin $(2 \mu \mathrm{M})$ or vehicle was intracranially infused, followed by an injection with cocaine or saline. Locomotor activity was monitored for an additional hour. A dose of $10 \mathrm{mg} / \mathrm{kg}$ intraperitoneal cocaine was administered to consistently increase locomotor activity, as preliminary experiments revealed that $5 \mathrm{mg} / \mathrm{kg}$ cocaine was not sufficient. Data were analyzed using a repeated-measures ANOVA with treatment as between-subjects and time as within-subjects factor.

Assessment of cannula placement. Following completion of the behavioral procedures, animals were deeply anesthetized using sodium pentobarbital $(60 \mathrm{mg} / \mathrm{ml}$, i.p.; Ceva Sante Animale). Subsequently, animals were perfused transcardially with $100 \mathrm{ml}$ of $0.9 \% \mathrm{NaCl}$, followed by $500 \mathrm{ml}$ of $4 \%$ paraformaldehyde in $0.1 \mathrm{M}$ PBS, pH 7.2. Brains were removed rapidly and postfixed for $1 \mathrm{~h}$ in the same fixative, then stored in $20 \%$ sucrose in $0.1 \mathrm{M}$ PBS, both at $4^{\circ} \mathrm{C}$. Coronal sections of $40 \mu \mathrm{m}$ were cut on a cryostat and subsequently stained with thionin for determination of the infusion sites.

\section{Results}

\section{Acute effect of insulin on DA release and its enhancement by} cocaine in NAc slices

Overall, the electrically evoked release of $\left[{ }^{3} \mathrm{H}\right] \mathrm{DA}$ in superfused NAc slices in excess of spontaneous tritium efflux amounted to $3.30 \pm 0.04 \%$ of total tissue radioactivity. Insulin slightly, but significantly, inhibited evoked $\left[{ }^{3} \mathrm{H}\right] \mathrm{DA}$ release in a concentration-dependent manner (Fig. $1 A$ ). Since a maximal inhibitory effect on evoked $\left[{ }^{3} \mathrm{H}\right] \mathrm{DA}$ was obtained at $10 \mathrm{nM}(\sim 13 \%$ inhibition, $\left.F_{(1,58)}=5.27, p<0.05\right)$, this concentration of insulin was

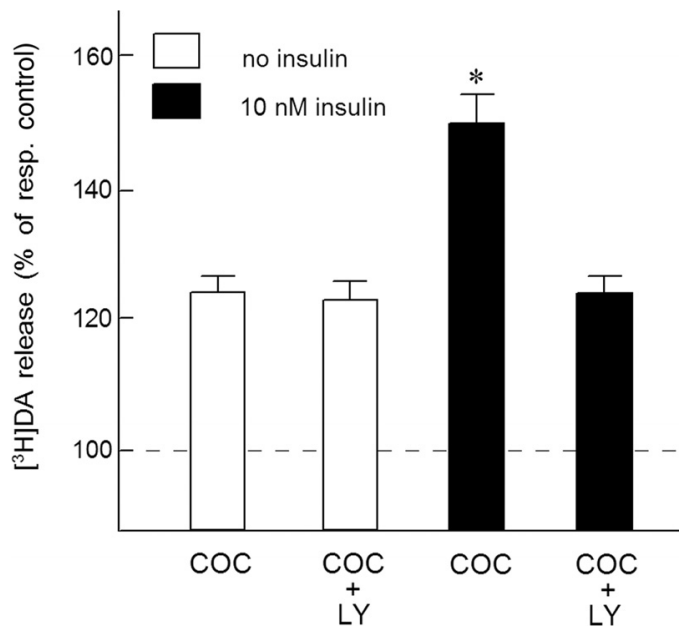

Figure 2. The PI3K inhibitor LY294002 blocks the insulin-induced increase of the DA releaseenhancing effect of cocaine in NAc slices. Slices, incubated with [ $\left.{ }^{3} \mathrm{H}\right] \mathrm{DA}$ (in the presence of $3 \mu \mathrm{m}$ desmethylimipramine), were superfused and stimulated electrically at $t=40 \mathrm{~min}$ for $10 \mathrm{~min}$. Insulin (10 nM), $1 \mu \mathrm{m}$ cocaine (COC) and $10 \mu \mathrm{m}$ LY294002 (LY) were added to the superfusion medium 20 min before depolarization and were present until the end of the experiment. Data are expressed as percentage of respective control (resp. control) $\left[{ }^{3} \mathrm{H}\right] \mathrm{DA}$ release in excess of spontaneous tritium efflux, i.e., evoked release in the absence and presence of insulin. Data represent means \pm SEM of 24 observations. ${ }^{*} p<0.01$, significantly different from the effect of cocaine in the absence of insulin.

used in all subsequent experiments. Cocaine dose-dependently enhanced electrically evoked $\left[{ }^{3} \mathrm{H}\right] \mathrm{DA}$ release, reaching its maximal effect at $1 \mu \mathrm{M}$. Figure $1 B$ shows that insulin profoundly potentiated this effect of cocaine. Accordingly, whereas $1 \mu \mathrm{M}$ cocaine increased electrically evoked $\left[{ }^{3} \mathrm{H}\right] \mathrm{DA}$ release from $3.16 \%$ to $3.79 \%$ of total tissue tritium in the absence insulin $(20 \%$ increase, $\left.F_{(1,46)}=5.00, p<0.05\right)$, cocaine increased evoked release from $2.74 \%$ to $3.93 \%$ of total tissue tritium in the presence of insulin $\left(43 \%\right.$ increase, $\left.F_{(1,46)}=12.16, p<0.01\right)$. Thus, insulin more than doubled the relative effect of $1 \mu \mathrm{M}$ cocaine on exocytotic DA release in NAc slices, indicating that insulin enhanced DAT function in DA nerve terminals.

In the presence of $10 \mu \mathrm{M}$ of the selective PI3K inhibitor LY294002, the inhibitory effect of insulin on electrically evoked $\left[{ }^{3} \mathrm{H}\right] \mathrm{DA}$ release was no longer observed. In these experiments, evoked $\left[{ }^{3} \mathrm{H}\right] \mathrm{DA}$ release in the absence and presence of $10 \mathrm{nM}$ insulin amounted to $3.25 \%$ and $2.91 \%$ of total tissue tritium, respectively $\left(F_{(1,46)}=4.67, p<0.05\right)$ and to $3.21 \%$ and $3.31 \%$ of total tissue tritium, respectively $\left(F_{(1,46)}=0.21\right.$, NS) when LY294002 was also present in the superfusion medium. Figure 2 shows that, in the presence of $10 \mathrm{~nm}$ insulin, the stimulatory effect of cocaine on electrically evoked $\left[{ }^{3} \mathrm{H}\right] \mathrm{DA}$ release was approximately twofold higher than that in the absence of the hormone $\left(F_{(1,46)}=\right.$ $10.24, p<0.01)$. In the presence of LY294002, however, insulin did not potentiate the effect of cocaine on evoked $\left[{ }^{3} \mathrm{H}\right] \mathrm{DA}$ release $\left(F_{(1,46)}\right.$ $=0.10$, NS), indicating the involvement of insulin receptors.

Since insulin tended to enhance electrically evoked release of $\left[{ }^{3} \mathrm{H}\right] \mathrm{DA}$ in the presence of cocaine $\left(F_{(1,94)}=2.69, p=0.07\right)$, rather than inhibiting release as observed in the absence of cocaine, it is conceivable that the hormone also has a slight releaseenhancing effect, independent of enhancement of DAT function, that is unmasked upon DAT blockade.

\section{Specificity of the regulatory role of insulin on} monoamine transporter function

The electrically evoked release of $\left[{ }^{3} \mathrm{H}\right] \mathrm{DA}$ in $\mathrm{CP}, \mathrm{mPFC}$, and OFC slices in excess of spontaneous tritium efflux amounted to $2.53 \pm$ 


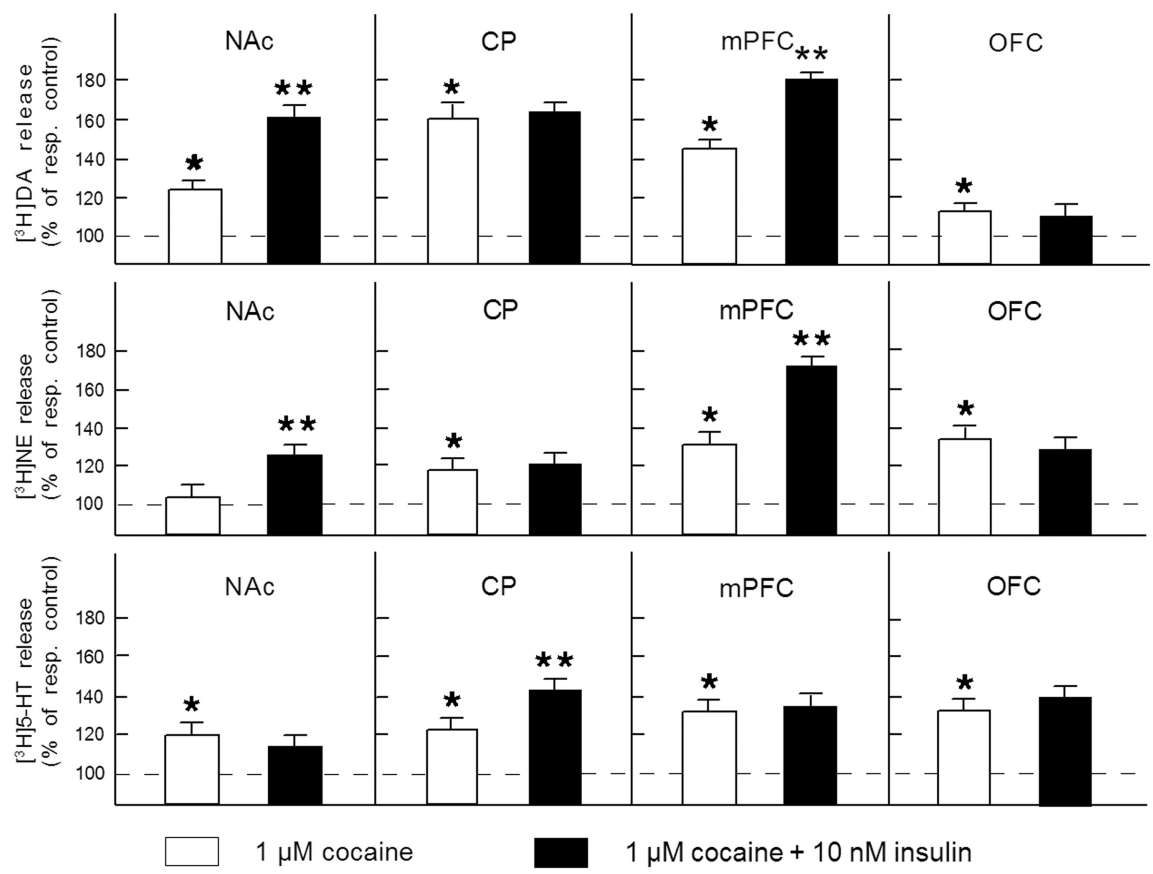

Figure 3. Region and neurotransmitter specificity of the regulatory role of insulin receptors. Slices of the NAc, $C P, \mathrm{mPFC}$, or OFC were incubated with $\left[{ }^{3} \mathrm{H}\right] \mathrm{DA}$ (in the presence of $3 \mu \mathrm{m}$ desmethylimipramine) or $\left[{ }^{3} \mathrm{H}\right] \mathrm{NE}$ or $\left[{ }^{3} \mathrm{H}\right] 5-\mathrm{HT}$ (both in the presence of $10 \mu \mathrm{M}$ GBR12909). Radiolabeled slices were superfused and stimulated electrically at $t=40 \mathrm{~min}$ for $10 \mathrm{~min}$. Insulin (10 nM) and cocaine $(1 \mu \mathrm{m})$ were added to the superfusion medium $20 \mathrm{~min}$ before depolarization and were present until the end of the experiment. The release-enhancing effects of cocaine are expressed as percentage of respective electrically evoked release in the absence or presence of insulin. Data represent means \pm SEM of $24-30$ observations. ${ }^{*} p<0.05$, significantly different from control release; ${ }^{* *} p<0.05$, significantly different from the effect of cocaine in the absence of insulin. resp. control, Respective control.

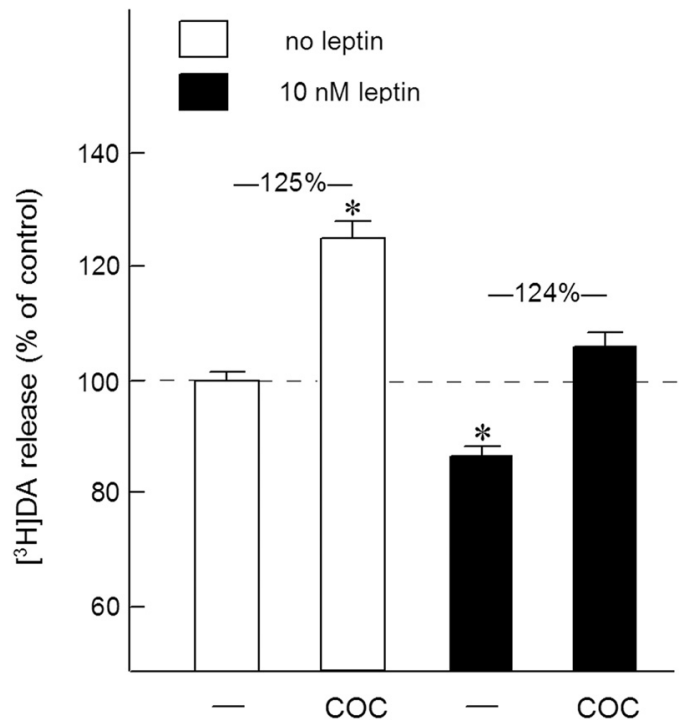

Figure 4. The effect of leptin on the electrically evoked $\left[{ }^{3} \mathrm{H}\right] \mathrm{DA}$ release and cocaine efficacy in NAC slices. Slices, incubated with [ $\left.{ }^{3} \mathrm{H}\right] \mathrm{DA}$ (in the presence of $3 \mu \mathrm{m}$ desmethylimipramine), were superfused and stimulated electrically at $t=40 \mathrm{~min}$ for $10 \mathrm{~min}$. Leptin (10 nM) and cocaine (COC; $1 \mu \mathrm{m}$ ) were added to the superfusion medium 20 min before depolarization and were present until the end of the experiment. The data are expressed as percentage of control $\left[{ }^{3} H\right] D A$ release in excess of spontaneous tritium efflux observed in the absence of insulin and cocaine. Data represent means \pm SEM of 24 observations. ${ }^{*} p<0.05$, significantly different from control release.

$0.06 \%, 12.53 \pm 0.24 \%$, and $7.16 \pm 0.12 \%$ of total tissue tritium, respectively. Insulin slightly inhibited evoked $\left[{ }^{3} \mathrm{H}\right] \mathrm{DA}$ release from mPFC slices ( $~ 9 \%$ inhibition, $\left.F_{(1,46)}=4.57, p<0.05\right)$, but did not alter evoked neurotransmitter release from $\mathrm{CP}$ and OFC slices (CP:
$F_{(1,46)}=0.26$, NS; OFC: $\left.F_{(1,46)}=0.31, \mathrm{NS}\right)$. As indicated in Figure 3, cocaine $(1 \mu \mathrm{M})$ appeared to increase the evoked release of $\left[{ }^{3} \mathrm{H}\right] \mathrm{DA}$ in slices of each of these brain regions $\left(F_{(1,46)}=4.31-6.56, p<0.05\right)$. In $\mathrm{mPFC}$ slices, the $\left[{ }^{3} \mathrm{H}\right] \mathrm{DA}$ release-enhancing effect of cocaine was potentiated in the presence insulin $\left(F_{(1,46)}=5.21, p<0.05\right)$, as observed in NAc slices.

The electrically evoked $\left[{ }^{3} \mathrm{H}\right] \mathrm{NE}$ release in NAc, CP, mPFC, and OFC slices amounted to $8.23 \pm 0.21 \%, 9.54 \pm 0.26 \%$, $5.52 \pm 0.14 \%$, and $6.18 \pm 0.20 \%$ of total tissue tritium, respectively. Insulin only caused a reduction of the evoked release of $\left[{ }^{3} \mathrm{H}\right] \mathrm{NE}(\sim 10 \%$ inhibition $)$ from NAc slices $\left(F_{(1,58)}=4.12, p<0.05\right)$ and $\mathrm{mPFC}$ slices $\left(F_{(1,58)}=4.32, p<0.05\right)$. Under the present experimental conditions, cocaine (1 $\mu \mathrm{M})$ did not enhance evoked $\left[{ }^{3} \mathrm{H}\right] \mathrm{NE}$ release in NAc slices in the absence of insulin $\left(F_{(1,46)}=0.54, \mathrm{NS}\right)$. As observed regarding the evoked release of $\left[{ }^{3} \mathrm{H}\right] \mathrm{DA}$, insulin potentiated the release-enhancing effect of cocaine on $\left[{ }^{3} \mathrm{H}\right] \mathrm{NE}$ release in NAc and $\mathrm{mPFC}$ slices $\left(F_{(1,46)}=4.76\right.$ and 5.21, respectively, $p<0.05)$, leaving the effect of cocaine in CP and OFC slices unchanged $\left(F_{(1,46)}=0.46\right.$ and 0.68 , respectively, NS) (Fig. 3 ).

The electrically evoked release of $\left[{ }^{3} \mathrm{H}\right] 5-\mathrm{HT}$ in slices of the NAc, CP, mPFC, and OFC amounted to $5.04 \pm 0.15 \%$, $6.08 \pm 0.19 \%, 6.52 \pm 0.23 \%$, and $8.27 \pm 0.28 \%$ of total tissue tritium, respectively. Insulin slightly reduced the evoked release of $\left[{ }^{3} \mathrm{H}\right] 5-\mathrm{HT}\left(\sim 10 \%\right.$ inhibition, $\left.F_{(1,46)}=4.17, p<0.05\right)$ and approximately doubled the release-enhancing effect of cocaine on evoked $\left[{ }^{3} \mathrm{H}\right] 5$-HT release in CP slices $\left(F_{(1,46)}=5.38, p<\right.$ $0.05)$, but did not alter evoked $\left[{ }^{3} \mathrm{H}\right] 5-\mathrm{HT}$ release $\left(F_{(1,46)}=0.17\right.$; $\mathrm{NS})$, nor the effects of cocaine thereon in NAc, mPFC, or OFC slices $\left(F_{(1,46)}=0.48,0.61\right.$, and 0.59 , respectively; NS) (Fig. 3 ).

Together, the occurrence of an inhibitory effect of insulin on exocytotic monoamine release was consistently associated with an enhancement of the relative stimulatory effect of cocaine on neurotransmitter release in the brain regions investigated, indicating the involvement of an insulin receptor-mediated increase in monoamine transporter function.

In addition to the brain region and neurotransmitter specificity of the effects of insulin, we investigated whether the adiposity hormone leptin causes similar presynaptic effects as insulin at DA nerve terminals. Figure 4 shows that a maximally effective concentration (data not shown) of leptin (10 nM) indeed caused an inhibitory effect on the electrically evoked release of $\left[{ }^{3} \mathrm{H}\right] \mathrm{DA}$ in NAc slices $\left(F_{(1,46)}=5.84, p<0.05\right)$. However, the DA-release enhancing effect of cocaine appeared to remain unchanged in the presence of leptin $\left(F_{(1,46)}=0.86, \mathrm{NS}\right)$.

\section{Effect of insulin on the efficacy of selective inhibitors of monoamine transporters in NAc slices}

As observed with cocaine (see above), the highly selective DAT inhibitor GBR12909 (1 $\mu \mathrm{M})$ enhanced the electrically evoked release of $\left[{ }^{3} \mathrm{H}\right] \mathrm{DA}$ in superfused NAc slices $\left(F_{(1,46)}=5.94, p<\right.$ 0.05). As indicated in Figure 5, this effect of GBR12909 (resulting 
from blockade of $\left[{ }^{3} \mathrm{H}\right] \mathrm{DA}$ reuptake) was more than doubled by exposure of the slices to $10 \mathrm{~nm}$ insulin $\left(F_{(1,46)}=9.53, p<0.01\right)$. Moreover, the selective NET inhibitor desmethylimipramine (1 $\mu \mathrm{M})$ enhanced the electrically evoked $\left[{ }^{3} \mathrm{H}\right] \mathrm{NE}$ release $\left(F_{(1,46)}=\right.$ $8.64, p<0.01$ ), provided that insulin was added to the superfusion medium. Figure 5 also shows that the selective serotonin transporter (SERT) inhibitor fluvoxamine $(1 \mu \mathrm{M})$ similarly enhanced the electrically evoked release of $\left[{ }^{3} \mathrm{H}\right] 5$-HT from NAc slices in the absence or presence of insulin $\left(F_{(1,46)}=0.11, \mathrm{NS}\right)$.

\section{Effect of intracranial infusion of insulin in the NAc on cocaine-sensitive inhibitory control}

In these experiments, 16 rats were trained in the 5-CSRTT. Two animals were excluded from all analyses; one rat died during the surgical procedure and one rat did not meet performance criteria during task acquisition and was therefore excluded. During test sessions, rats completed all 100 trials. Since preliminary experiments revealed that local administration of insulin in the NAc reduced premature responding in the 5-CSRTT and that a $2 \mu \mathrm{M}$ insulin infusion was optimally effective in this respect, we further examined the effect of this concentration of insulin on cocaine-sensitive inhibitory control. As we have previously shown (van Gaalen et al., 2006), cocaine (5 $\mathrm{mg} / \mathrm{kg}$, i.p. $)$ increased premature responding $\left(F_{(1,13)}=36.76, p<\right.$ $0.001)$. Most importantly, in addition to its inhibitory effect on impulsivity, NAc insulin $(2 \mu \mathrm{M})$ appeared to profoundly potentiate the relative stimulatory effect of cocaine (Fig. 6) (insulin $X$ cocaine interaction: $F_{(1,13)}=6.97, p<$ $0.05)$. Thus, in the absence of insulin, cocaine increased premature responding from $23.5 \%$ to $38.1 \%$ (62\% increase; $t_{(13)}$ $=2.26, p<0.05)$, whereas in the presence of insulin, this relative increase in premature responding by cocaine occurred to a much larger extent, i.e., from $12.3 \%$ to $47.1 \%$ (283\% increase; $t_{(13)}=7.61, p<$ $0.001)$. Interestingly, these behavioral observations closely resemble the neurochemical effects of insulin on neurotransmitter release described above. With regard to other behavioral parameters in the 5-CSRTT, some modest significant effects were found following NAc insulin infusion and peripheral cocaine injections (Table 1). Thus, NAc insulin increased accurate choice compared with vehicle infusion $t_{(13)}=2.99, p<0.01$; main effect insulin: $F_{(1,13)}=0.79$, NS; cocaine: $F_{(1,13)}=$ $0.46, \mathrm{NS}$; insulin $\times$ cocaine: $F_{(1,13)}=6.56$, $p<0.05)$ and cocaine by itself increased the number of omissions compared with all other drug combinations (vehicle/saline, $t_{(13)}=3.43, p<0.005$; insulin/saline, $t_{(13)}=2.68, p<0.005$; insulin/ cocaine, $t_{(13)}=2.42, p<0.05$; main effect insulin: $F_{(1,13)}=2.31, \mathrm{NS}$; cocaine: $F_{(1,13)}=7.22, p<0.05$; insulin $\times$ cocaine: $F_{(1,13)}=10.91$, $p<0.01)$. Finally, the combination of insulin and cocaine speeded response latencies compared with vehicle/saline treatment $\left(t_{(13)}=\right.$ 2.55, $p<0.05$; main effect insulin: $F_{(1,13)}=5.86, p<0.05$; cocaine: $F_{(1,13)}=0.43$, NS; insulin $\times$ cocaine: $F_{(1,13)}=3.80$, NS). Feeder latencies were not altered by administration of insulin, cocaine, or their combination (insulin: $F_{(1,13)}=2.59$, NS; cocaine: $F_{(1,13)}=1.00, \mathrm{NS}$; insulin $\times$ cocaine: $F_{(1,13)}=$ $1.78, \mathrm{NS})$. saline $(p<0.001)$.

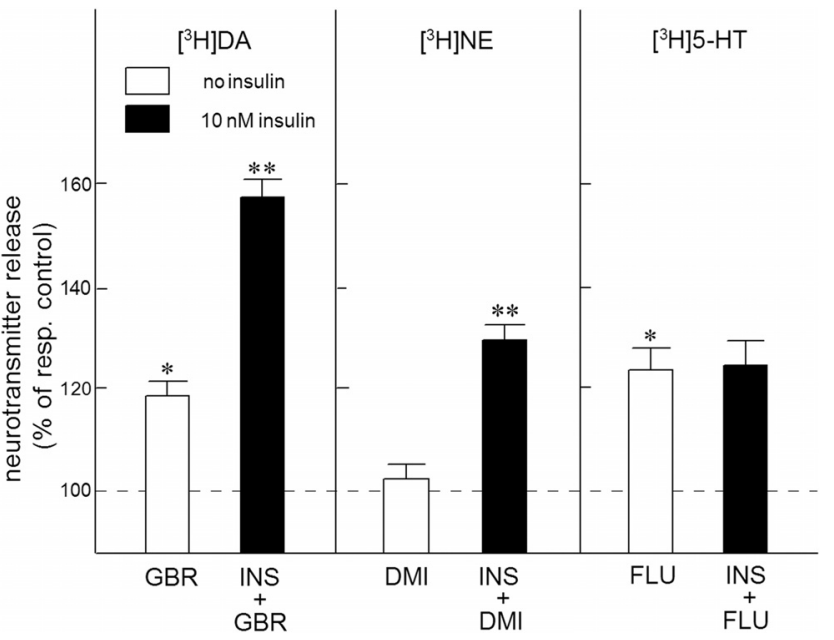

Figure 5. The effect of insulin on the efficacy of monoamine transporter inhibitors in the NAc. Slices of the NAc were incubated with $\left[{ }^{3} \mathrm{H}\right] \mathrm{DA}$ (in the presence of $3 \mu \mathrm{m}$ desmethylimipramine), or $\left[{ }^{3} \mathrm{H}\right] \mathrm{NE}$ or $\left[{ }^{3} \mathrm{H}\right] 5-\mathrm{HT}$ (both in the presence of $10 \mu \mathrm{m}$ GBR12909). Radiolabeled slices were superfused and stimulated electrically at $t=40 \mathrm{~min}$ for $10 \mathrm{~min}$. Insulin (10 nm; INS), GBR12909 (1 $\mu \mathrm{M} ; \mathrm{GBR}$ ), desmethylimipramine (1 $\mu \mathrm{m}$; DMI) or fluvoxamine (1 $\mu \mathrm{m} ; \mathrm{FLU})$ were added to the superfusion medium 20 min before depolarization and were present until the end of the experiment. The release-enhancing effects of the uptake inhibitors were expressed as percentage of respective control (resp. control) release in excess of spontaneous tritium efflux in the absence or presence of insulin. Data represent means \pm SEM of 24 observations. ${ }^{*} p<0.05$, significantly different from control release in the absence of insulin; ${ }^{* *} p<0.01$, significantly different from the effect of cocaine in the absence of insulin.
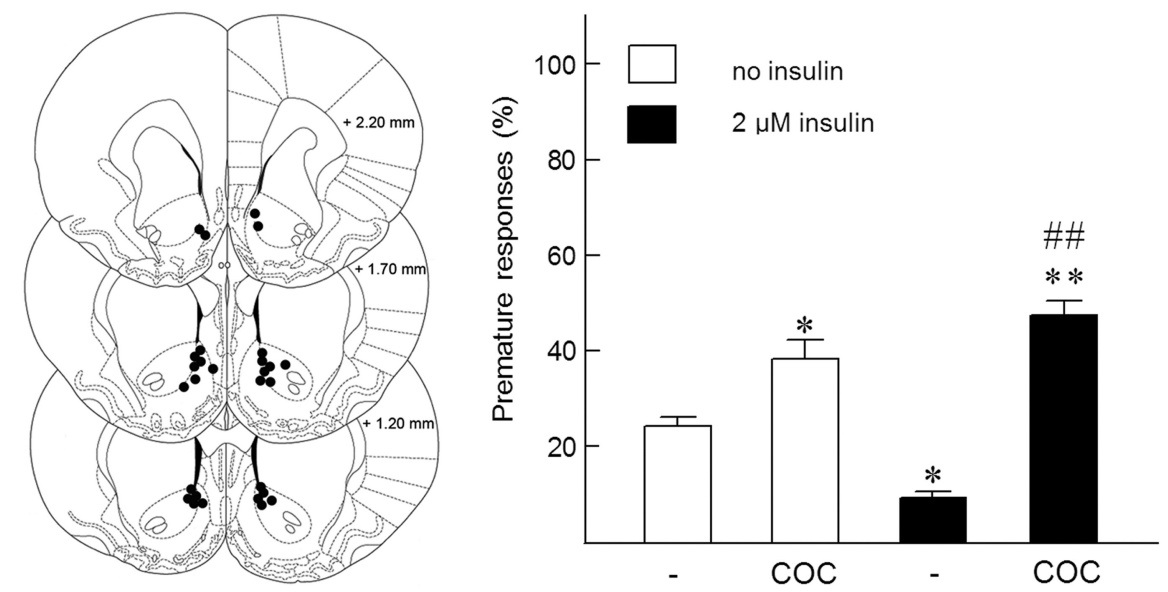

Figure 6. Effect of NAc insulin on motor impulsivity in the 5-CSRTT. Left, Schematic drawing of coronal sections depicting cannula placement into the NAc [adopted from Paxinos and Watson (1998)]. Right, Effects of intracranial application of insulin into the NAc on motor impulsivity and on the stimulatory effect of cocaine $(5 \mathrm{mg} / \mathrm{kg}$ i.p.; $\mathrm{COC}$ ). Note that the effects of cocaine on premature responding amounted to $\sim 60 \%$ and $280 \%$ of respective control values in the absence (open bars) and presence (closed bars) of insulin. ${ }^{*} p<0.05$ and ${ }^{* *} p<0.005$, significantly different from vehicle/saline; ${ }^{\# \#}$ significantly different from insulin/

\section{Effect of intracranial infusion of insulin in the NAc on cocaine-induced locomotor activity}

Initially, thirty-two rats were equipped with cannulae aimed at the NAc and the effects of insulin and cocaine or their combination on locomotor activity were tested in a between-subjects design with eight animals per treatment. Two animals died during surgery, and three animals were excluded due to cannula misplacement (resulting group sizes: vehicle + saline, $n=8$; vehicle + cocaine, $n=7$; insulin + saline, $n=6$, and insulin + cocaine, $n=6$ ). 
Table 1. Effects of intra-accumbal insulin $(2 \mu \mathrm{m})$ and systemic cocaine $(5 \mathrm{mg} / \mathrm{kg}$, i.p.) on auxiliary behavioral measures in the 5-CSRTT

\begin{tabular}{lllcl}
\hline & $\begin{array}{l}\text { Accurate } \\
\text { choice (\%) }\end{array}$ & $\begin{array}{l}\text { Response } \\
\text { latency (ms) }\end{array}$ & Omissions & $\begin{array}{l}\text { Feeder } \\
\text { latency (ms) }\end{array}$ \\
\hline Vehicle-saline & $80.9 \pm 2.4$ & $318 \pm 9$ & $7.6 \pm 1.1$ & $1264 \pm 105$ \\
Vehicle-cocaine & $83.5 \pm 1.7$ & $314 \pm 12$ & $16.1 \pm 2.5^{*}$ & $1851 \pm 427$ \\
Insulin-saline & $85.4 \pm 2.2^{*}$ & $325 \pm 13$ & $9.1 \pm 1.3$ & $1265 \pm 99$ \\
Insulin-cocaine & $80.8 \pm 2.2$ & $298 \pm 8^{*}$ & $9.8 \pm 1.3$ & $1623 \pm 326$ \\
\hline
\end{tabular}

Data are means \pm SEM obtained in 14 rats. ${ }^{*} p<0.05$, compared to vehicle-saline treatment.
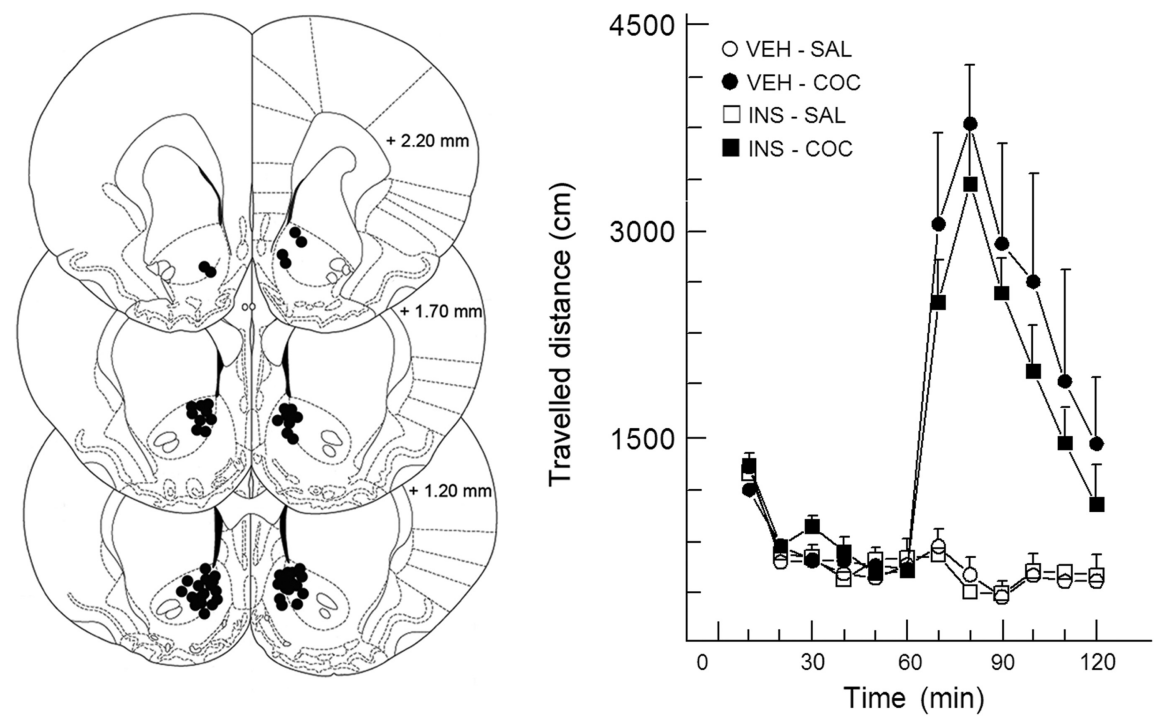

Figure 7. NAc insulin does not affect locomotor activity. Left, Schematic drawing of coronal sections depicting cannula placement into the NAc [adopted from Paxinos and Watson (1998)]. Right, Lack of effects of intracranial application of insulin into the NAc on locomotor activity and on the stimulatory effect of cocaine (10 mg/kg i.p.). VEH, Vehicle; SAL, saline; COC, cocaine.

Unlike intraperitoneal administration of $5 \mathrm{mg} / \mathrm{kg}$ cocaine (data not shown) (Herges and Taylor, 1999), a dose of $10 \mathrm{mg} / \mathrm{kg}$ caused a consistent hyperlocomotor response (Fig. 7) (treatment: $F_{(3,23)}=10.80, p<0.001$; time $\times$ treatment: $F_{(33,253)}=7.15, p<$ $0.001)$. Further analyses revealed that both groups treated with cocaine differed from the saline-treated groups. In contrast to the behavioral effects in the cognitive task, insulin $(2 \mu \mathrm{M})$ infusion into the NAc did not alter the locomotor effects of cocaine (treatment: $F_{(1,11)}=0.36, \mathrm{NS}$; time $\times$ treatment: $\left.F_{(11,121)}=0.37, \mathrm{NS}\right)$. Likewise, insulin by itself did also not alter the distance traveled compared with vehicle and saline-treated controls (treatment: $F_{(1,12)}=0.17$, NS; time $\times$ treatment: $\left.F_{(11,132)}=0.42, \mathrm{NS}\right)$.

\section{Discussion}

Our present neurochemical and behavioral data show, for the first time, that (1) insulin enhances cocaine-sensitive monoamine transporter function in rat NAc, thereby displaying brainregion specificity, and (2) NAc insulin reduces impulsive behavior and enhances cocaine-induced impulsivity, in agreement with the crucial role of monoamine neurotransmission in the NAc in inhibitory response control. Therefore, the pancreatic hormone insulin may play a role in inhibitory control deficits such as that observed in drug abuse, obesity, and attention deficit hyperactivity disorder (ADHD).

Considering the involvement of insulin in cognitive and motivational processes that depend on DA neurotransmission, insulin receptors and their downstream substrates (IRS-2 and PI3K) in rat brain are densely expressed in DA neurons within the ventral tegmental area (VTA) and activation of these receptors enhances PI3K activity and DAT mRNA expression (Figlewicz et al., 1994; Pardini et al., 2006; Figlewicz and Benoit, 2009). Moreover, insulin receptor activation appeared to increase the surface expression and function of DAT in rat striatum, enhancing DA reuptake in a P13Kdependent manner (Patterson et al., 1998; Carvelli et al., 2002; Garcia et al., 2005; Lute et al., 2008). Similarly, insulin receptor-mediated $\mathrm{PI} 3 \mathrm{~K}$ activation may acutely promote NET activity in nerve terminals, albeit without altering its cell surface expression (Apparsundaram et al., 2001). Experimentally induced diabetes appeared to reduce amphetamine-stimulated psychomotor activity, presumably through insulinregulated DAT activity in the striatum (Marshall, 1978; Murzi et al., 1996; Owens et al., 2005). Accordingly, streptozocin-induced hypoinsulinemia attenuated the DA-releasing action of amphetamine by inhibiting PI3K signaling downstream of insulin receptors and reducing the surface expression and function of DAT in the striatum (Carvelli et al., 2002; Galici et al., 2003; Williams et al., 2007; Lute et al., 2008). These studies suggest that behavioral effects of amphetamine mediated by striatal DA release are insulin-dependent. However, since central neuroadaptations may occur upon long-lasting insulin depletion, the use of a diabetic model may not be ideal to assess the acute effects of insulin on normal brain function. Therefore, we examined the role of insulin in cocaine-sensitive monoamine transporter function and monoamine release neurochemically and behaviorally under nonpathological conditions, i.e., in nondiabetic rats.

We found that insulin alone inhibited electrically evoked $\left[{ }^{3} \mathrm{H}\right] \mathrm{DA}$ release and potentiated the (relative) stimulatory effect of cocaine and that of the selective DAT inhibitor GBR12909 on exocytotic DA release in NAc slices, indicating enhanced DAT function. Moreover, the selective PI3K-inhibitor LY294002 abolished these insulin effects, indicating the involvement of insulin receptor signaling. Such acute effects of insulin were also observed in mPFC slices, but not in DS and OFC slices. These data suggest that insulin primarily regulates DAT activity in the prefrontal cortical-ventral striatal pathway that mediates the neurocognitive effects of addictive drugs (Everitt and Robbins, 2005; Pattij and Vanderschuren, 2008). Regarding the specificity of this insulin effect, the adiposity hormone leptin similarly reduced evoked DA release in NAc slices. Apparently, leptin not only inhibits the activity of DA neurons within the VTA (Hommel et al., 2006), but also reduces DA neurotransmission presynaptically in the NAc. In this respect, it is of interest to note that NAc DA release appeared to be reduced (rather than enhanced) in leptin-deficient (ob/ob) mice (Fulton et al., 2006), indicating that chronic reduction of leptin levels in mutant mice may cause neuroadaptations in DA neurons. The inhibitory effect of leptin on NAc DA release, in contrast to that of insulin, was not associated with potentiation of release-enhancing effect of cocaine, indicating that leptin does not exert its presynaptic inhibitory action by enhancing DAT function, but perhaps through hyperpolarization as in the VTA (Hommel et al., 2006). 
Although cocaine blocks DAT, NET, and SERT function (Rothman and Baumann, 2003), the psychoactive effects of cocaine primarily involve enhanced DA neurotransmission. However, depending on the behavioral effect of cocaine, enhanced NE and 5-HT release (upon blockade of NET and SERT) may also play a role (Drouin et al., 2002; Homberg et al., 2008; Hall et al., 2009). Therefore, we also examined the effect of insulin on the evoked $\left[{ }^{3} \mathrm{H}\right] \mathrm{NE}$ and $\left[{ }^{3} \mathrm{H}\right] 5$-HT release and its enhancement by cocaine in brain slices. Cocaine (and the selective NET inhibitor desmethylimipramine) only enhanced evoked $\left[{ }^{3} \mathrm{H}\right] \mathrm{NE}$ release from NAc slices when insulin was added to the superfusion medium. Apparently, only in the presence of insulin does $\left[{ }^{3} \mathrm{H}\right] \mathrm{NE}$ reuptake play a prominent role in determining the overall efflux of the neurotransmitter from NAc slices measured under our superfusion conditions. Moreover, insulin strongly enhanced the stimulatory effect of cocaine on $\left[{ }^{3} \mathrm{H}\right] \mathrm{NE}$ release in $\mathrm{mPFC}$ slices, but did not affect it in CP or OFC slices. In contrast, insulin only potentiated the effect of cocaine on $\left[{ }^{3} \mathrm{H}\right] 5-\mathrm{HT}$ release in $\mathrm{CP}$ slices. Since an inhibitory effect of insulin on electrically evoked monoamine release in brain slices was associated with potentiation of the release-enhancing effect of monoamine transporter blockers, our study reveals that insulin presynaptically enhances the function of monoamine transporters in frontal cortical and striatal rat brain regions.

Given these distinct neurochemical effects of insulin, the hormone may play a modulatory role in various cognitive and motivational processes. In this respect, we also studied the role of NAc insulin in cocaine-sensitive impulsive action, since monoamine neurotransmission in the NAc is crucial for inhibitory response control and cocaine-induced motor impulsivity in rats (Cole and Robbins, 1987, 1989; van Gaalen et al., 2006; Pezze et al., 2007; Pattij et al., 2007; Pattij and Vanderschuren, 2008). We observed that insulin infused into the NAc reduced premature responses in the 5-CSRTT, resembling its inhibitory effect on monoamine release in this brain region. Moreover, as observed for the monoamine-release enhancing effects of cocaine, the increase in impulsivity induced by a peripheral injection of cocaine was potentiated by application of insulin into the NAc. These observations suggest that insulin receptors may modulate cocaine-sensitive inhibitory response control by enhancing monoamine transporter function in the NAc. Importantly, the profound behavioral effects of NAc insulin on 5-CSRTT performance were restricted to impulsive behavior since only modest effects were found on other behavioral parameters. Of particular interest in this regard, NAc insulin slightly improved visuospatial attention, consistent with the role of NAc DA neurotransmission in visuospatial attention (Pattij et al., 2007; Pezze et al., 2007) and an inverse relationship between impulsivity and visuospatial attention (Dalley et al., 2008).

Considering the role of monoamine receptors in the effects of insulin on inhibitory response control, activation of D1 as well as D2/3 DA receptors in the NAc is known to enhance motor impulsivity in rats (Van Gaalen et al., 2006, Dalley et al., 2007; Pattij et al., 2007). Although this also holds true for psychostimulantinduced locomotor activity (Ikemoto, 2002), we did not find an effect of NAc insulin on locomotor activity and its enhancement by cocaine, indicating that NAc insulin does not affect behaviors that engage the DA system in general.

The role of insulin in monoamine transporter function and impulsivity that we discovered may have important pathophysiological implications. For instance, regarding motivation for food, intraventricular insulin (and leptin) application in rats appeared to reverse place preference conditioned with a high-fat diet (Figlewicz et al., 2004) and to reduce sucrose self-administration (Figlewicz et al., 2006). Moreover, considering the prevalence of obesity and type 2 diabetes, a high-fat diet and genetic obesity is known to cause insulin resistance in rat brain attenuating the central inhibitory effect of insulin on food intake (Figlewicz and Benoit, 2009). Since peripheral insulin resistance in nondiabetic humans appears to be associated with attenuated insulin-evoked responses in the brain (Anthony et al., 2006), it is possible that individuals with insulin resistance are at risk of obesity because of altered functioning of the insulinsensitive mesocorticolimbic system and its progressive dysregulation upon consumption of highly palatable foods. With regard to the role of NAc insulin in impulsive behavior, it is of interest that impulsivity is often associated with drug abuse (Coffey et al., 2003) and obesity (Nederkoorn et al., 2006) and that there is a considerable incidence of drug addiction (Wilens, 2004) and obesity (Cortese et al., 2008) in patients suffering from ADHD. In this respect, recent studies showed that motor impulsivity in rats may be a risk factor for the initiation of drug abuse, the switch to compulsive drug-seeking and cue-induced relapse behavior (Dalley et al., 2007; Belin et al., 2008; Diergaarde et al., 2008, Economidou et al., 2009). Moreover, we showed that poor impulse control in rats not only predicts behavioral hyperresponsiveness to cocaine and nicotine, but also escalation of sucrose seeking and hypersensitivity to sucrose-associated stimuli (Diergaarde et al., 2009). It is therefore conceivable that individual differences in brain insulin levels or insulin sensitivity play a role in addiction (including obesity) proneness. Future studies, for example, on the behavioral effects of altered insulin receptor gene expression in the NAc, should shed more light on the pathophysiological impact of our findings. This is of importance, since targeting insulin receptor signaling in the brain may provide a novel pharmacotherapy for inhibitory control disorders such as drug addiction, obesity, and ADHD.

\section{References}

Anthony K, Reed LJ, Dunn JT, Bingham E, Hopkins D, Marsden PK, Amiel SA (2006) Attenuation of insulin-evoked responses in brain networks controlling appetite and reward in insulin resistance: the cerebral basis for impaired control of food intake in metabolic syndrome? Diabetes 55:2986-2992.

Apparsundaram S, Sung U, Price RD, Blakely RD (2001) Traffickingdependent and -independent pathways of neurotransmitter transporter regulation differentially involving p38 mitogen-activated protein kinase revealed in studies of insulin modulation of norepinephrine transport in SK-N-SH cells. J Pharmacol Exp Ther 299:666-677.

Belin D, Mar AC, Dalley JW, Robbins TW, Everitt BJ (2008) High impulsivity predicts the switch to compulsive cocaine-taking. Science 320:1352-1355

Carvelli L, Morón JA, Kahlig KM, Ferrer JV, Sen N, Lechleiter JD, LeebLundberg LM, Merrill G, Lafer EM, Ballou LM, Shippenberg TS, Javitch JA, Lin RZ, Galli A (2002) PI 3-kinase regulation of dopamine uptake. J Neurochem 81:859-869.

Coffey SF, Gudleski GD, Saladin ME, Brady KT (2003) Impulsivity and rapid discounting of delayed hypothetical rewards in cocaine-dependent individuals. Exp Clin Psychopharmacol 11:18-25.

Cole BJ, Robbins TW (1987) Amphetamine impairs the discriminative performance of rats with dorsal noradrenergic bundle lesions on a 5-choice serial reaction time task: new evidence for central dopaminergicnoradrenergic interactions. Psychopharmacology (Berl) 91:458-466.

Cole BJ, Robbins TW (1989) Effects of 6-hydroxydopamine lesions of the nucleus accumbens septi on performance of a 5-choice serial reaction time task in rats: implications for theories of selective attention and arousal. Behav Brain Res 33:165-179.

Cortese S, Angriman M, Maffeis C, Isnard P, Konofal E, Lecendreux M, Purper-Ouakil D, Vincenzi B, Bernardina BD, Mouren MC (2008) At- 
tention-deficit/hyperactivity disorder (ADHD) and obesity: a systematic review of the literature. Crit Rev Food Sci Nutr 48:524-537.

Dalley JW, Fryer TD, Brichard L, Robinson ES, Theobald DE, Lääne K, Peña Y, Murphy ER, Shah Y, Probst K, Abakumova I, Aigbirhio FI, Richards HK, Hong Y, Baron JC, Everitt BJ, Robbins TW (2007) Nucleus accumbens D2/3 receptors predict trait impulsivity and cocaine reinforcement. Science 315:1267-1270.

Dalley JW, Mar AC, Economidou D, Robbins TW (2008) Neurobehavioral mechanisms of impulsivity: fronto-striatal systems and functional neurochemistry. Pharmacol Biochem Behav 90:250-260.

Diergaarde L, Pattij T, Poortvliet I, Hogenboom F, de Vries W, Schoffelmeer AN, De Vries TJ (2008) Impulsive choice and impulsive action predict vulnerability to distinct stages of nicotine seeking in rats. Biol Psychiatry 63:301-308.

Diergaarde L, Pattij T, Nawijn L, Schoffelmeer AN, De Vries TJ (2009) Trait impulsivity predicts escalation of sucrose seeking and hypersensitivity to sucrose-associated stimuli. Behav Neurosci 123:794-803.

Drouin C, Blanc G, Villégier A-S, Glowinski J, Tassin JP (2002) Critical role of $\alpha_{1}$-adrenergic receptors in acute and sensitized locomotor effects of d-amphetamine, cocaine and GBR12783: influence of preexposure conditions and pharmacological characteristics. Synapse 43:51-61.

Economidou D, Pelloux Y, Robbins TW, Dalley JW, Everitt BJ (2009) High impulsivity predicts relapse to cocaine-seeking after punishment-induced abstinence. Biol Psychiatry 65:851-856.

Everitt BJ, Robbins TW (2005) Neural systems of reinforcement for drug addiction: from actions to habits to compulsion. Nat Neurosci 8:14811489.

Figlewicz DP, Benoit SC (2009) Insulin, leptin and food reward: update 2008. Am J Physiol Regul Integr Comp Physiol 296:R9-R19.

Figlewicz DP, Szot P, Chavez M, Woods SC, Veith RC (1994) Intraventricular insulin increases dopaminergic transporter mRNA in rat VTA/substantia nigra. Brain Res 664:331-334.

Figlewicz DP, Bennett J, Evans SB, Kaiyala K, Sipols AJ, Benoit SC (2004) Intraventricular insulin and leptin reverse place preference conditioned with high-fat diet in rats. Behav Neurosci 118:479-487.

Figlewicz DP, Bennett JL, Naleid AM, Davis C, Grimm JW (2006) Intraventricular insulin and leptin decrease sucrose self-administration in rats. Physiol Behav 89:611-616.

Fulton S, Pissios P, Manchon RP, Stiles L, Frank L, Pothos EN, Maratos-Flier E, Flier JS (2006) Leptin regulation of the mesoaccumbens dopamine pathway. Neuron 51:811-822.

Galici R, Galli A, Jones DJ, Sanchez TA, Saunders C, Frazer A, Gould GG, Lin RZ, France CP (2003) Selective decreases in amphetamine selfadministration and regulation of dopamine transporter function in diabetic rats. Neuroendocrinology 77:132-140.

Garcia BG, Wei Y, Moron JA, Lin RZ, Javitch JA, Galli A (2005) Akt is essential for insulin modulation of amphetamine-induced human dopamine transporter cell-surface redistributuin. Mol Pharmacol 68:102-109.

Giros B, Jaber M, Jones SR, Wightman RM, Caron MG (1996) Hyperlocomotion and indifference to cocaine and amphetamine in mice lacking the dopamine transporter. Nature 379:606-612.

Hall FS, Li XF, Randall-Thompson J, Sora I., Murphy DL, Lesch KP, Caron M, Uhl GR (2009) Cocaine-conditioned locomotion in dopamine transporter, norepinephrine transporter and 5-HT transporter knockout mice. Neuroscience 15:870-880.

Herges S, Taylor DA (1999) Modulation of cocaine-induced locomotor activity, rears and head bobs by application of WAY 100635 into the dorsal and median raphe nuclei of the rat. Naunyn Schmiedebergs Arch Pharmacol 360:129-134.

Homberg JR, De Boer SF, Raas ø HS, Olivier JD, Verheul M, Ronken E, Cools AR, Ellenbroek BA, Schoffelmeer AN, Vanderschuren LJ, De Vries TJ, Cuppen E (2008) Adaptations in pre- and postsynaptic 5-HT1A receptor function and cocaine supersensitivity in serotonin transporter knockout rats. Psychopharmacology (Berl) 200:367-380.

Hommel JD, Trinko R, Sears RM, Georgescu D, Liu ZW, Gao XB, Thurmon JJ, Marinelli M, Dileone RJ (2006) Leptin receptor signaling in midbrain dopamine neurons regulates feeding. Neuron 51:678-680.
Ikemoto S (2002) Ventral striatal anatomy of locomotor activity induced by cocaine, $\mathrm{d}$-amphetamine, dopamine and D1/D2 agonists. Neuroscience 113:939-955.

Kern W, Peters A, Fruehwald-Schultes B, Deininger E, Born J, Fehm HL (2001) Improving influence of insulin on cognitive function in humans. Neuroendocrinology 74:270-280.

Khoshbouei H, Sen N, Guptaroy B, Johnson L, Lund M, Gnegy A, Galli A, Javitch JA (2004) N-terminal phosphorylation of the dopamine transporter is required for amphetamine-induced efflux. PLoS Biol 2:e78.

Lute BJ, Khoshbouei H, Saunders C, Sen N, Lin RZ, Javitch JA, Galli A (2008) PI3K signalling supports amphetamine-induced dopamine efflux. Biochem Biophys Res Commun 372:656-661.

Marks JL, Maddison J, Eastman CJ (1988) Subcellular localization of rat brain insulin binding sites. J Neurochem 50:774-781.

Marshall JF (1978) Further analysis of the resistance of the STZ-treated rat to D-amphetamine. Pharmacol Biochem Behav 8:281-286.

Murzi E, Contreras Q, Teneud L, Valecillos B, Parada MA, De Parada MP, Hernandez L (1996) Diabetes decreases limbic extracellular dopamine in rats. Neurosci Lett 202:141-144.

Nederkoorn C, Braet C, Van Eijs Y, Tanghe A, Jansen A (2006) Why obese children cannot resist food: the role of impulsivity. Eating Behav 7:315-322.

Owens WA, Sevak RJ, Galici R, Chang X, Javors MA, Galli A, France CP, Daws LC (2005) Deficits in dopamine clearance and locomotion in hypoinsulinemic rats unmask novel modulation of dopamine transporters by amphetamine. J Neurochem 94:1402-1410.

Pardini AW, Nguyen HT, Figlewicz DP, Baskin DG, Williams DL, Kim F, Schwartz MW (2006) Distribution of insulin receptor substrate-2 in brain areas involved in energy homeostasis. Brain Res 1112:169-178.

Patterson TA, Brot MD, Zavosh A, Schenk JO, Szot P, Figlewicz DP (1998) Food deprivation decrease nRNA and activity of the rat dopamine transporter. Neuroendocrinology 68:11-20.

Pattij T, Vanderschuren LJ (2008) The neuropharmacology of impulsive behaviour. Tr Pharmacol Sci 29:192-199.

Pattij T, Janssen MC, Vanderschuren LJ, Schoffelmeer ANM, van Gaalen MM (2007) Involvement of dopamine D1 and D2 receptors in the nucleus accumbens core and shell in inhibitory response control. Psychopharmacology (Berl) 191:587-598.

Paxinos G, Watson C (1998) The rat brain in stereotaxic coordinates. Sydney: Academic.

Pezze MA, Dalley JW, Robbins TW (2007) Differential roles of dopamine D1 and D2 receptors in nucleus accumbens in attentional performance on the five-choice serial reaction time task. Neuropsychopharmacology 32:273-283.

Rothman RB, Baumann MH (2003) Monoamine transporters and psychostimulant drugs. Eur J Pharmacol 31:23-40.

Schoffelmeer AN, Rice KC, Jacobson AE, Van Gelderen JG, Hogenboom F, Heijna MH, Mulder AH (1988) Mu, delta- and kappa-opioid receptormediated inhibition of neurotransmitter release and adenylate cyclase activity in rat brain slices: studies with fentanyl isothiocyanate. Eur J Pharmacol 154:169-178.

Schulingkamp RJ, Pagano TC, Hung D, Raffa RB (2000) Insulin receptors and insulin action in the brain: review and clinical implications. Neurosci Biobehav Rev 24:855-872.

van Gaalen MM, Brueggeman RJ, Bronius PF, Schoffelmeer AN, Vanderschuren LJ (2006) Behavioral disinhibition requires dopamine receptor activation. Psychopharmacology (Berl) 187:73-85.

Wilens TE (2004) Impact of ADHD and its treatment on substance abuse in adults. J Clin Psychiatry 65 [Suppl 3]:38-45.

Williams JM, Owens WA, Turner GH, Saunders C, Dipace C, Blakely RD, France CP, Gore JC, Daws LC, Avison MJ, Galli A (2007) Hypoinsulinemia regulates amphetamine-induced recerse transport of dopamine. PLoS Biol 5:e274.

Woods SC, Schwartz MW, Baskin DG, Seeley RJ (2000) Food intake and the regulation of body weight. Annu Rev Psychol 51:255-277.

Zhao WQ, Alkon DL (2001) Role of insulin receptor in learning and memory. Mol Cell Endocrinol 177:125-134. 